\title{
Drying of Acerola (Malpighia emarginata D. C.) by- Product: Evolution of Active Compounds in Function of Time
}

Marcela Perozzi Tedesco ${ }^{1}$

https://orcid.org/0000-0003-1081-5126

Carla Alves Monaco Lourenço ${ }^{1}$

https://orcid.org/0000-0002-2523-4386

Vitor Augusto dos Santos Garcia ${ }^{1}$

https://orcid.org/0000-0002-7011-616X

\section{Fernanda Maria Vanin ${ }^{1}$}

https://orcid.org/ 0000-0001-5583-7092

Rosemary Aparecida de Carvalho ${ }^{1 *}$

https://orcid.org/ 0000-0002-4284-0994

${ }^{1}$ University of São Paulo, Faculty of Animal Science and Food Engineering, Pirassununga, São Paulo, Brazil;

Editor-in-Chief: Paulo Vitor Farago

Associate Editor: Jane Manfron Budel

Received: 2020.01.24; Accepted: 2021.03.30.

*Correspondence: rosecarvalho@usp.br, +55-19-35654355 (R.A.C.).

\section{HIGHLIGHTS}

- The Page model can predict the moisture content of acerola by-product.

- The convective drying does not present a great loss of the antioxidant capacity.

- Increase of ascorbic acid and total vitamin $\mathrm{C}$ levels at the end of drying at $40^{\circ} \mathrm{C}$.

- Proanthocyanidins did not show large variations during drying at all temperatures.

Abstract: The objective of this study was to evaluate the behavior of active compounds concentration present in the industrial by-product of acerola during drying using convective dehydration at 40,50 and $60{ }^{\circ} \mathrm{C}$. For this, flavones and flavonols, total proanthocyanidins, vitamin $\mathrm{C}$, total phenolic content and antioxidant capacity as function of drying time were determined. The drying data were adjusted using the models of Page, Lewis, Henderson \& Pabis, Modified Page and Logarithmic. In relation to the applied models, Page model presented the best fit. Acerola by-products dried at $40^{\circ} \mathrm{C}$ showed higher concentrations of active compounds and higher antioxidant capacity. Although the drying process provoked changes in concentration of the active compounds, in the studied temperature range, significant concentrations of those bioactive compounds were observed. Thus, acerola by-product may present potential for application in different foods.

Keywords: Vitamin C; antioxidant capacity; drying; Page model; compounds actives. 


\section{INTRODUCTION}

According to USDA [1] the acerola (Malpighia emarginata DC) is among the fruits with the highest content of vitamin $C(1677.6 \mathrm{mg} / \mathrm{100 \textrm {g }})$, which is higher than other fruits, known to have high percentages of vitamin $\mathrm{C}$, such as guava $(228.3 \mathrm{mg} / 100 \mathrm{~g})$, orange $(53.2 \mathrm{mg} / 100 \mathrm{~g})$ and lemon $(53 \mathrm{mg} / 100 \mathrm{~g})$. In addition to vitamin $\mathrm{C}$, acerola also contains other compounds with high antioxidant capacity, like carotenoids, flavonoids and anthocyanins [2]. Acerola is an acid fruit and highly perishable, so the consumption of the fruit is restricted and most of the production is destined to the processing of juice or pulp. From fruit processing and export of processed fruits, significant amounts of waste are generated annualy. The waste is not recycled on a large scale, rather it is used only as fertilizer or discarded.

The acerola by-product is composed of peel, seeds and residual pulp and constitutes about $18 \%$ of the total weight of the fruit [3]. Several authors reported that the acerola by-product presents relevant concentrations of active compounds. Da Silva and coauthors [4] observed that the content of anthocyanins in the seed exceeded $70 \%$ the value found in the pulp $(144.27 \mathrm{mg} / 100 \mathrm{~g})$ and flavonoids were detected in a concentration of $98.5 \mathrm{mg} / 100 \mathrm{~g}$ of dry residue, while in the pulp these compounds were not detected. The previously dried acerola by-product is usually characterized in relation to the antioxidant properties [4-10] and some suggest applications in food ingredient [7] and/or food supplements [8], due to the high concentration of antioxidant compounds.

Nobrega and coauthors [7] found that after the drying process at different temperatures $(60,70$ and $80{ }^{\circ} \mathrm{C}$ ) and air velocity $(4.5$ and $6 \mathrm{~m} / \mathrm{s}$ ) the acerola by-product presented retention of total phenolics (26 to $31 \%$ ), carotenoids (50 to $61 \%$ ), anthocyanins (23 to $36 \%$ ), proanthocyanidins (21\%), ascorbic acid (40 to $70 \%$ ) and antioxidant activity (20\%). Silva and coauthors [9] studied acerola by-product dried in a rotary dryer under different conditions of temperature $\left(70.6-159.3^{\circ} \mathrm{C}\right)$ and air velocity $(1.30-3.20 \mathrm{~m} / \mathrm{s})$ and observed retention of phenolic compounds and flavonoids, after the drying process, with concentrations higher than fresh sample. Duzzioni and coauthors [10] evaluated the process of drying acerola by-products by fixed-bed dryer and reported that drying conditions play an important role in the quality of the final product, especially in relation to antioxidant compounds.

Studies evaluating the effect of temperature on the concentration of active compounds during the drying of acerola by-product are incipient. The rational exploitation of fruit by-products besides relieving disposal problems, would also provide raw material for the development of a new functional product. Therefore, in view of this technological challenge, the objective of this work was to evaluate the behavior of the concentration of active compounds present in the industrial by-product of acerola during the convective drying with hot air $\left(40,50\right.$ and $\left.60^{\circ} \mathrm{C}\right)$.

\section{MATERIAL AND METHODS}

\section{Material}

Acerola by-product from the processing of frozen pulp production was donated by Frutamil Comércio de Frutas e Sucos Ltda (Pratânia, SP, Brazil), after processing the by-product was frozen and transported under refrigeration to carry out the experiments. In the laboratory the by-product was stored at $-22^{\circ} \mathrm{C}$. The solvents, reagents and standards used were: ethanol (Synth, Diadema, Brazil), ascorbic acid (Sigma-Aldrich, St Louis, MO, USA), sulfuric acid $\left(\mathrm{H}_{2} \mathrm{SO}_{4}\right.$, Merck, Darmstadt, Germany), dithiothreitol (DTT, Sigma- USA), Folin-Ciocalteu (Sigma-Aldrich, St. Louis, MO, USA), sodium carbonate (Synth, Diadema, Brazil), gallic acid (Sigma-Aldrich, St Louis, MO, USA), fluorescein (Sigma-Aldrich (Sigma-Aldrich, St Louis, MO, USA), Trolox (Sigma-Aldrich, St. Louis, MO, USA), 2,20-azobis (2-methylpropionamidine) dihydrochloride (AAPH) (Synth, Diadema, Brazil), quercetin (Sigma-Aldrich, St Louis, MO, USA), ferrous sulfate heptahydrate $\left(\mathrm{FeSO}_{4} .7 \mathrm{H}_{2} \mathrm{O}\right.$, Synth, Diadema, Brazil), n-butanol (Dynamic Chemical Contemporary, Diadema, Brazil ), hydrochloric acid (Synth, Diadema, Brazil), quebracho tannin (Unitan, Buenos Aires, Argentina).

\section{Kinetic drying}

Drying was conducted in a forced convection oven as proposed by Goula and coauthors [11] with changes in the drying parameters. An oven (MA 035/5, Marconi, Piracicaba, SP, Brazil) equipped with galvanized metal perforated trays $(55 \times 80 \mathrm{~cm})$ and air flow parallel to the trays with a fixed speed of $1.6 \mathrm{~m} / \mathrm{s}$ was used. Acerola by-product $(250 \mathrm{~g})$, previously defrosted (12h, room temperature) was spread in aluminum trays $(\phi=25 \mathrm{~cm})$ keeping thickness constant at $6 \mathrm{~mm}$, and dried at 40, 50 and 
$60{ }^{\circ} \mathrm{C}$. Mass variation (tray + acerola by-product) during drying was determined using a semianalytical balance (Adventurer, Ohaus Corporation, Parsippany, NJ, USA) at 10 min intervals during the first hour and $20 \mathrm{~min}$ in the others until reach constant mass (three consecutive weighing where the absolute mass variation was less than $0.1 \%$ ). In order to obtain the curves of the moisture ratio versus drying time (each point in the curve corresponds to the average of three values of moisture ratio) experiments were carried out in triplicate. Acerola by-product moisture content was determined at $105^{\circ} \mathrm{C}$, for a period of 24 hours [12] and the moisture calculated according to Equation 1.

$$
M=\frac{w_{1}-w_{2}}{w_{2}} 100
$$

Where: $M=$ moisture at any time ( $g$ water/g dry matter); $w_{1}=$ initial mass of the sample $(g) ; w_{2}=$ final dry mass of the sample.

\section{Mathematical modeling}

The analysis of experimental data of drying was carried out as function of moisture ratio and drying time. The moisture ratio (MR) was determined using Equation 2. The moisture content (M) at any moment of drying (g water/g dry matter) was calculated according to Equation 3 [13].

$$
\begin{aligned}
& M R=\frac{M-M_{e}}{M_{0}-M_{e}} \\
& M=\frac{\left(W_{0}-W_{a e}\right)-W_{s a}}{W_{s a}}
\end{aligned}
$$

Where: $\mathrm{MR}=$ moisture ratio (dimensionless); $\mathrm{Me}_{\mathrm{e}}$ equilibrium moisture content ( $\mathrm{g}$ water/g dry matter); $\mathrm{M}_{0=}$ initial moisture content ( $g$ water/g dry mass); $W_{0}=$ initial mass of sample $(g) ; W_{a e}=$ amount of evaporated water (g); $\mathrm{W}_{\mathrm{sa}}=$ sample dry matter mass $(\mathrm{g})$;

Experimental data of convection drying were adjusted using the models described in Table 1 and a non-linear regression analysis tool in OriginPro 9. The adjustments of the models were evaluated, according to Ertekin and Yaldiz [14], using: coefficient of determination $\left(R^{2}\right)$, reduced X-square (Equation 4), root mean square error (Equation 5) and modeling efficiency (Equation 6).

$$
\begin{aligned}
& X^{2}=\frac{\sum_{i=1}^{N}\left(M R_{\text {exp }, i}-M R_{\text {pre }, i}\right)^{2}}{N-n} \\
& R M S E=\left[\frac{1}{N} \sum_{i=1}^{N}\left(M R_{\text {pre }, i}-M R_{\text {exp }, i}\right)^{2}\right]^{1 / 2} \\
& E F=\frac{\sum_{i=1}^{N}\left(M R_{\text {exp }, i}-M R_{\text {exp }, \text { mean }}\right)^{2}-\sum_{i=1}^{N}\left(M R_{\text {pre }, i}-M R_{\text {exp }, i}\right)^{2}}{\sum_{i=1}^{N}\left(M R_{\text {exp }, i}-M R_{\text {expmean }}\right)^{2}}
\end{aligned}
$$

Where: MRexp,i = experimental moisture ratio; $M R p r e, \mathrm{i}=$ predicted moisture ratio; $\mathrm{N}=$ number of observations; $\mathrm{n}=$ number of constants in drying model; MRexp, mean = mean value of experimental moisture ratio.

Table 1. Models used to adjust the data of the drying curves of the acerola by-product.

\begin{tabular}{lll}
\hline Model & \multicolumn{1}{c}{ Equation } & \multicolumn{1}{c}{ Reference } \\
\hline Lewis & $M R=\exp (-k t)$ & Lewis [15] \\
Henderson \& Pabis & $M R=a \exp (-k t)$ & Henderson and Pabis [16] \\
Page & $M R=\exp \left(-k t^{n}\right)$ & Page [17] \\
Modified Page & $M R=\exp \left[-(k t)^{n}\right]$ & Overhults and coauthors [18] \\
Logarithmic & $M R=a \exp (-k t)+b$ & Yağcıoğlu and coauthors [19] \\
\hline
\end{tabular}

\section{Characterization of acerola by-product}

\section{Color parameters}

The color parameters (CIELab coordinates), Luminosity $\left(\mathrm{L}^{*}\right)$, chroma $\mathrm{a}^{*}\left(\mathrm{a}^{*}\right)$ and chroma $\mathrm{b}^{*}\left(\mathrm{~b}^{*}\right)$ were determined at two-hour intervals using a HunterLab colorimeter (Miniscan XE, HunterLab) with the operating conditions illuminant/observer equal to $\mathrm{D} 65 / 10^{\circ}$. 


\section{Active compounds determination and antioxidant capacity}

The effect of temperature and drying time on the concentration of active compounds and antioxidant capacity were evaluated at two-hour intervals. The samples were ground in a domestic food processor (Oster, FPSTHB2610R-017, China). For the evaluation of active compounds, extractions were carried out using $70 \%$ ethanol as solvent, as proposed by Correia and coauthors [20]. Samples (1g) were dispersed in $40 \mathrm{ml}$ of $70 \%$ ethanol (5 min, magnetic stirring at $750 \mathrm{rpm}$ ) in an ice bath, and filtered (Whatman filter paper No. 1) under reduced pressure. After the process extraction, the obtained extract was stored under refrigeration $\left(-18.0 \pm 0.5^{\circ} \mathrm{C}\right)$ until analysis.

\section{Flavones and flavonols, total proanthocyanidins and vitamin C}

Flavones and flavonols concentration was determined according to Neves and coauthors [21]. Aliquots of extracts ( $3 \mathrm{~mL}$ ) obtained from the extraction of acerola by-product were added to $2 \mathrm{~mL}$ of aluminum chloride (5\%). The solutions were vortexed (Vortex, IKA, Staufen, Germany) and held at $30{ }^{\circ} \mathrm{C}$ for $30 \mathrm{~min}$. The absorbance of the solutions was determined using a spectrophotometer (Genesys 10S UV-vis, Thermo Scientific, SP, Brazil) at $441 \mathrm{~nm}$. Blank was prepared for each sample ( $3 \mathrm{~mL}$ of extract and $2 \mathrm{~mL}$ of water without aluminum chloride). The calibration curve was obtained using quercetin as standard $(0-22 \mu \mathrm{g} / \mathrm{mL})$ and the concentrations of flavone and flavonol were expressed as $\mathrm{mg}$ quercetin/g dry sample.

Determination of total proanthocyanidins was performed as proposed by Porter and coauthors [22]. Aliquots $(250 \mu \mathrm{L})$ were added to $2.5 \mathrm{~mL}$ of Porter's reagent $\left(154 \mathrm{mg}\right.$ of $\mathrm{FeSO}_{4} .7 \mathrm{H}_{2} \mathrm{O}$ per liter of 3:2 n-butanol:hydrochloric acid). The solution was homogenized and maintained at $95^{\circ} \mathrm{C}$ (water bath MA127/GT60, Marconi, Piracicaba, SP, Brazil) for 30min. The standard curve was prepared using quebracho tannin varying the concentration from 0 to $2.4 \mathrm{mg} / \mathrm{mL}$. After cooling, the absorbance was determined at $550 \mathrm{~nm}$ (spectrophotometer, Genesys 10S UV-vis, Thermo Scientific, SP, Brazil) and the results expressed as mg quebracho tannin equivalents (QTE)/ g dry sample.

The determination of vitamin $\mathrm{C}$ was performed by high performance liquid chromatography using ascorbic acid as standard according to methodology proposed by Sánchez-Mata and coauthors [23], $1.8 \mathrm{mM} \mathrm{H}_{2} \mathrm{SO}_{4}$ solution $(\mathrm{pH} 2.6)$ was used as the mobile phase at a flow rate of $0.9 \mathrm{~mL} / \mathrm{min}$. Extract samples were filtered at Millipore $0.45 \mathrm{~mm}$ before injection into the chromatographic system (Shimatzu - Promenience, LC 20 AD pump with automatic injector SIL20-HT). Detection was performed at $245 \mathrm{~nm}$ (UV-visible detector Thermo Separation Spectra UV100) and the column used was Prominence LC 20. To quantify the dehydroascorbic acid, samples were reduced with dithiothreitol (DTT) and injected into the chromatographic system. The reduction was performed by adding $0.2 \mathrm{ml}$ of $20 \mathrm{mg}$ DTT $/ \mathrm{ml}$ solution to $1 \mathrm{~mL}$ of the filtrate and kept in the absence of light for 2 $\mathrm{h}$. The concentration of total ascorbic acid was expressed in $\mathrm{mg}$ of total ascorbic acid/g of dry sample.

\section{Total phenolic contents and ORAC assay}

The total phenolic contents by Folin-Ciocalteau was determined according to Singleton and coauthors [24]. Aliquots of previously diluted extracts $(0.5 \mathrm{~mL})$ were added to $2.5 \mathrm{~mL}$ of FolinCiocalteu reagent $(1: 10 ; \mathrm{v} / \mathrm{v})$. The solution was homogenized and kept at rest (5 minutes). Then to it was added $2.0 \mathrm{~mL}$ of sodium carbonate solution (7.5\%). The solutions were homogenized (Vortex 1 , IKA, Staufen, Germany) and kept for 2 hours in the absence of light. Absorbance reading was performed on a spectrophotometer (Genesys 10S UV-vis, Thermo Scientific, SP, Brazil) at $740 \mathrm{~nm}$. Results were expressed as mg of gallic acid equivalent (GAE)/g dry sample using a standard curve of gallic acid (range of concentration between 0 and $64 \mu \mathrm{g} / \mathrm{mL}$ ).

The oxygen radical absorption capacity (ORAC) method was determined by decaying the fluorescence resulting from its oxidation according to $\mathrm{Ou}$ and coauthors [25] and Rodrigues and coauthors [26]. Aliquots of $25 \mu \mathrm{L}$ (standard, control, or extract), $150 \mu \mathrm{L}$ of fluorescein and $25 \mu \mathrm{L}$ of AAPH were transferred to a black microplate (96 WELL, PP, F-BOTTOM, Greiner Bio-One GmbH, Kremsmunster, Austria). The solutions were diluted with $75 \mathrm{mM}$ phosphate buffer (pH 7.4), also used as control. Samples were analyzed using Optima Fluostar fluorometer (BMG Labtech, Offenburg, Germany), using excitation length of $493 \mathrm{~nm}$ and emission of $515 \mathrm{~nm}$ at $37^{\circ} \mathrm{C}$. The fluorescence of the samples was determined (1 min intervals) until their total decay. Trolox was used as standard (8$96 \mu \mathrm{M})$ and the results were expressed as $\mu \mathrm{mol}$ Trolox Equivalents/g dry sample. 


\section{Scanning electron microscopy}

Structural characteristics of the acerola residue (in natura and dried) were evaluated using scanning electron microscope model TM-3000 (Hitachi) at 15kV. For analysis, the in natura samples were freeze dried (Terroni, LC 1500, São Carlos, SP). The samples were ground and stored in desiccator with silica before analysis.

\section{RESULTS}

\section{Kinetic drying}

The initial moisture content of the acerola by-product was approximately $80 \%$ (wet basis) and the obtained drying times until constant mass were $9 \mathrm{~h} 40 \mathrm{~min}, 11 \mathrm{~h}$ and $14 \mathrm{~h}$ at 60,50 and $40{ }^{\circ} \mathrm{C}$, respectively (Figure 1). In the drying curves, logarithmic reduction of the moisture ratio as function of time can be verified for all temperatures. The increase in temperature caused a reduction in drying time. According to Zhu and Shen [27] shorter drying times are obtained at higher temperatures due to the increase of drying rate, this occurs due to the increase in the heat transfer potential between the air and the samples, favoring the evaporation of water.

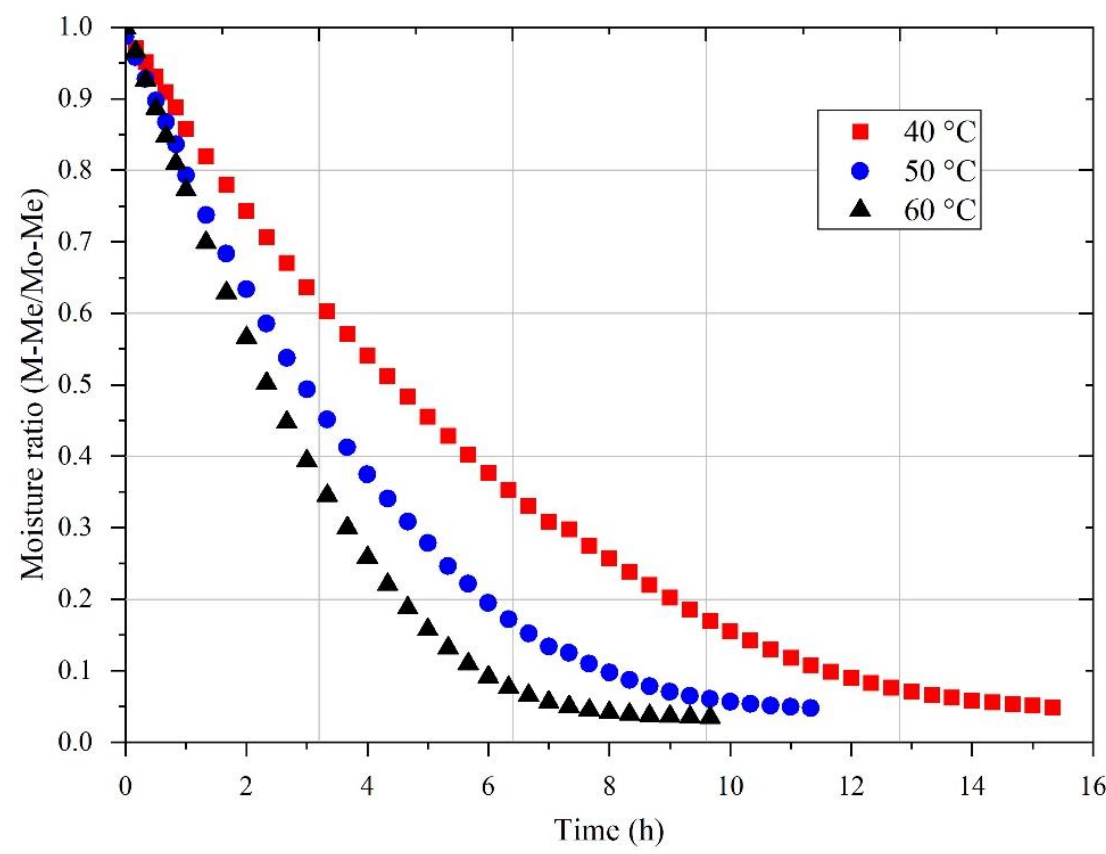

Figure 1. Effect of the drying temperature on the moisture ratio of acerola by-product in a thickness of $6 \mathrm{~mm}$ during the drying.

Table 2 shows the statistical constants and values (coefficient of determination, reduced Xsquare, mean square error and modeling efficiency) of the data adjustments to the mathematical models studied. It was verified that all the models evaluated fitted the experimental data and the coefficients of determination presented good values $\left(R^{2}>0.988\right)$. As explained by Ertekin and Yaldiz [14], the lower the values of the reduced X-square and mean square error (closer zero), the better the goodness of the fit, while to predict the ability of the model, EF is evaluated, 1 being the highest value.

For the temperature of $60^{\circ} \mathrm{C}$, Page model presented the best values of the statistical parameters $\mathrm{R}^{2}, \mathrm{X}^{2}, \mathrm{RMSE}$ and EF. Modified Page also presented the same values of statistical parameters but with difference in the value of the constant $\mathrm{k}$. For the temperature of $50{ }^{\circ} \mathrm{C}$, the Page model also presented the best results of the statistical parameters with $\mathrm{R}^{2}, \mathrm{X}^{2}$, RMSE and $E F$. At the drying temperature of $40{ }^{\circ} \mathrm{C}$, although the logarithmic model presented better $R^{2}$, the values of $X^{2}$, RMSE and EF were better for the Page model. Therefore, Page model is the most adequate to provide a prediction of the effect of temperature on the moisture ratio of the acerola by-product. 
Table 2. Statistical results (coefficient of determination, $R^{2}$, reduced chi-square, $X^{2}$, Root-mean-square deviation, RMSE and modeling efficiency, EF) of the Lewis, Handerson \& Pabis, Page, modified Page and logarithmic models and their constants and coefficients in different drying conditions $\left(40,50\right.$ and $\left.60^{\circ} \mathrm{C}\right)$ of acerola by-product.

\begin{tabular}{|c|c|c|c|c|c|c|}
\hline Model & & Constant & $\mathbf{R}^{2}$ & $\mathrm{X}^{2}$ & RMSE & EF \\
\hline \multicolumn{7}{|l|}{$40^{\circ} \mathrm{C}$} \\
\hline Lewis & $\mathrm{k}$ & 0.1741 & 0.9959 & 0.0012 & 0.0338 & 0.9862 \\
\hline \multirow{2}{*}{$\begin{array}{l}\text { Henderson \& } \\
\text { Pabis }\end{array}$} & $\mathrm{k}$ & 0.1737 & \multirow{2}{*}{0.9959} & \multirow{2}{*}{0.0012} & \multirow{2}{*}{0.0341} & \multirow{2}{*}{0.9881} \\
\hline & a & 0.9983 & & & & \\
\hline \multirow{2}{*}{ Page } & $\mathrm{k}$ & 0.1315 & \multirow{2}{*}{0.9988} & \multirow{2}{*}{0.0002} & \multirow{2}{*}{0.0142} & \multirow{2}{*}{0.9980} \\
\hline & $\mathrm{n}$ & 1.1625 & & & & \\
\hline \multirow{3}{*}{ Logarithmic } & $\mathrm{k}$ & 0.1353 & \multirow{3}{*}{0.9991} & \multirow{3}{*}{0.0003} & \multirow{3}{*}{0.0157} & \multirow{3}{*}{0.9975} \\
\hline & a & 1.1254 & & & & \\
\hline & $\mathrm{b}$ & -0.1312 & & & & \\
\hline \multirow{2}{*}{ Modified Page } & $\mathrm{k}$ & 0.1746 & \multirow{2}{*}{0.9988} & \multirow{2}{*}{0.0002} & \multirow{2}{*}{0.0141} & \multirow{2}{*}{0.9980} \\
\hline & $\mathrm{n}$ & 1.1633 & & & & \\
\hline \multicolumn{7}{|l|}{$50^{\circ} \mathrm{C}$} \\
\hline Lewis & $\mathrm{k}$ & 0.2638 & 0.9885 & 0.0015 & 0.0378 & 0.9839 \\
\hline \multirow{2}{*}{$\begin{array}{l}\text { Henderson \& } \\
\text { Pabis }\end{array}$} & $\mathrm{k}$ & 0.2638 & \multirow{2}{*}{0.9901} & \multirow{2}{*}{0.0011} & \multirow{2}{*}{0.0325} & \multirow{2}{*}{0.9901} \\
\hline & $\mathrm{a}$ & 1.0357 & & & & \\
\hline \multirow{2}{*}{ Page } & $\mathrm{k}$ & 0.1721 & \multirow{2}{*}{0.9983} & 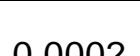 & 00116 & 09980 \\
\hline & $\mathrm{n}$ & 1.2506 & & 0.0002 & 0.0140 & 0.9980 \\
\hline & $\mathrm{k}$ & 0.1993 & & & & \\
\hline Logarithmic & $\mathrm{a}$ & 1.1705 & 0.9971 & 0.0005 & 0.0206 & 0.9960 \\
\hline & $\mathrm{b}$ & -0.1547 & & & & \\
\hline Modified Page & $\mathrm{k}$ & 0.2449 & 09983 & 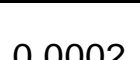 & 00146 & 09980 \\
\hline Fivuned age & $n$ & 1.2515 & 0.0000 & $0.000<$ & 0.0140 & 0.5000 \\
\hline $60^{\circ} \mathrm{C}$ & & & & & & \\
\hline Lewis & $\mathrm{k}$ & 0.2946 & 0.9919 & 0.0028 & 0.0523 & 0.9697 \\
\hline Henderson \& & $\mathrm{k}$ & 0.3142 & 00915 & 00010 & 00410 & 00912 \\
\hline Pabis & $\mathrm{a}$ & 1.0122 & 0.9945 & 0.0019 & 0.0419 & 0.9043 \\
\hline Pago & $\mathrm{k}$ & 0.2702 & 09996 & 00003 & 00158 & 09078 \\
\hline rage & $n$ & 1.1775 & 0.5950 & 0.0000 & 0.0100 & 0.5910 \\
\hline & $\mathrm{k}$ & 0.2485 & & & & \\
\hline Logarithmic & $\mathrm{a}$ & 1.1164 & 0.9973 & 0.0013 & 0.0350 & 0.9890 \\
\hline & $b$ & -0.1090 & & & & \\
\hline Modified Page & $\mathrm{k}$ & 0.3291 & 09996 & 00003 & 00158 & 09978 \\
\hline tvivanted rage & $\mathrm{n}$ & 1.1776 & 0.9996 & 0.0003 & 0.0158 & 0.5910 \\
\hline
\end{tabular}

As reported by Araya-Farias and coauthors [28], the constant rate (k), or drying constant in Page model is temperature dependent and it is related with the moisture diffusion coefficient. Thus, as the temperature increases, $\mathrm{k}$ increases. The drying constant $(\mathrm{k})$ at $60^{\circ} \mathrm{C}$ was approximately twice the drying constant at $40^{\circ} \mathrm{C}$ (Table 2), so it can be said that the temperature affects the process duration as well as the final moisture content of the samples. The final moisture content of dried acerola byproducts at 40,50 and $60{ }^{\circ} \mathrm{C}$ was $14.59 \pm 1.93,11.59 \pm 1.65,8.58 \pm 0.57 \%$. Duzzioni and coauthors [10] evaluated the process of drying by fixed-bed dryer and reported final moisture $<8 \%,<8.5 \%$ and $<4 \%$ for acerola by-products dried at 40,50 and $60{ }^{\circ} \mathrm{C}$, regardless of the air velocity used. The differences could be explained by differences in acerola by-products used in the different studies, as well as, 
dryer specifications, as air velocity, surface area (which can enhance more or less radiation to samples), between others.

Other authors have obtained similar results. Goula and coauthors [11] studying drying of grape pomace at $60^{\circ} \mathrm{C}$ obtained a good coefficient of determination for the studied models: Lewis, Page; Modified Page, Handerson \& Pabis and Logarithmic. Zhu and Shen [27] evaluated different parameters in the drying process (temperature, air velocity and peach slice thickness) in convective dryer, and verified that the Page model presented better adaptation to the experimental data.

\section{Characterization of acerola by-product}

\section{Color parameters}

The color parameters of acerola by-product (Figure 2) underwent changes during the drying and were temperature dependent. The luminosity parameter $\left(L^{*}\right)$ was reduced for all evaluated temperatures. For higher temperatures, this drop was more pronounced, but in the end of the drying, all showed close value. The color parameters $a^{*}$ and $b^{*}$ gradually decreased throughout the drying process in all evaluated temperature $\left(40,50,60^{\circ} \mathrm{C}\right)$ tending a dark red-yellow color, possibly due to non-enzymatic darkening. According to Sinha and coauthors [29] caramelization, Maillard reaction, oxidation of ascorbic acid and oxidative condensation of tannic compounds are possible nonenzymatic darkening mechanism.

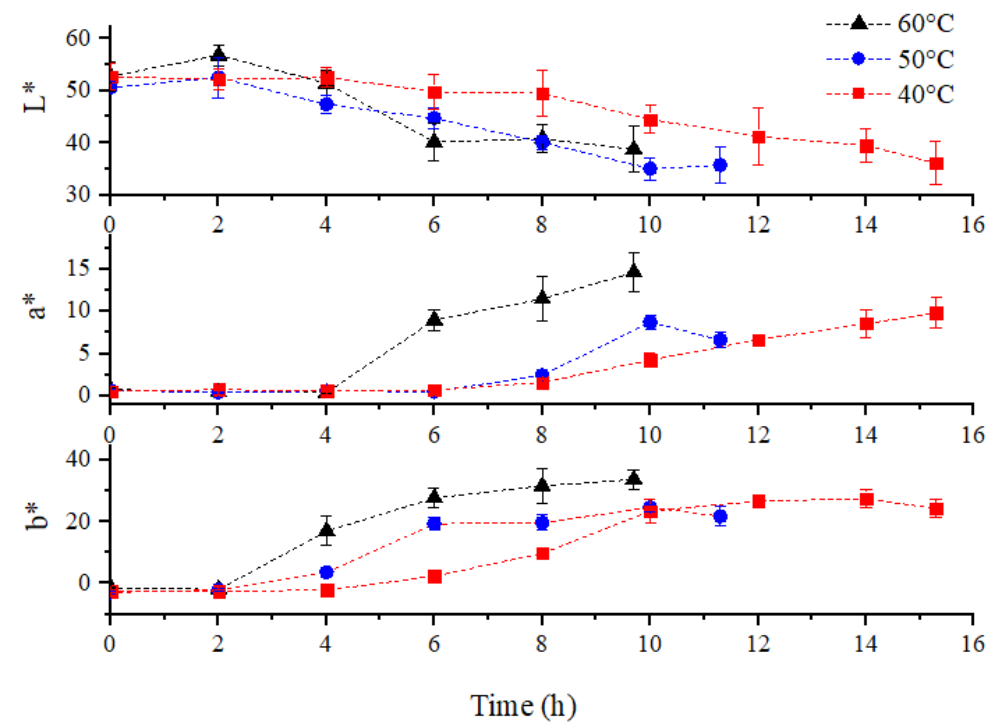

Figure 2. Effect of the drying temperature $\left(40,50\right.$ and $\left.60^{\circ} \mathrm{C}\right)$ on color parameters of acerola by-product during the drying.

\section{Flavones and flavonols, total proanthocyanidins and vitamin $C$}

The results of flavones and flavonols are presented in Figure $3 a$. In contrast, at $50{ }^{\circ} \mathrm{C}$ there was a gradual loss during drying, flavones and flavonols content of acerola by-product after drying at 40 and $60^{\circ} \mathrm{C}$ were higher than those obtained for the fresh residue, with values in the range of 350 to $800 \mathrm{mg}$ quercetin / $100 \mathrm{~g}$ extract, being the highest concentration observed at $60{ }^{\circ} \mathrm{C}$ after $8 \mathrm{~h}$ of drying. The increase in the concentration of flavones and flavonols may be related to several factors, such as rate of degradation, structure of these compounds, among others.

Silva and coauthors [9] drying acerola residue by rotary dryer also observed higher concentration of flavonoids in dried residue, presenting a percentage increase of $249 \%$ in relation to the fresh residue.

Proanthocyanidins did not show large variations during drying at all temperatures demonstrating that this class of antioxidant compounds is more thermally stable (Figure 3b). Chamorro and coauthors [30] also observed the thermal stability of these compounds. The authors investigated the effect of heat treatment on polyphenolic content in grape pomace and grape seed extract (aqueous extraction and spray drying) in a furnace and autoclave $\left(100{ }^{\circ} \mathrm{C}\right.$ for 15,30 and $60 \mathrm{~min}$ ) and found that the treatment did not affect the procyanidin content. 


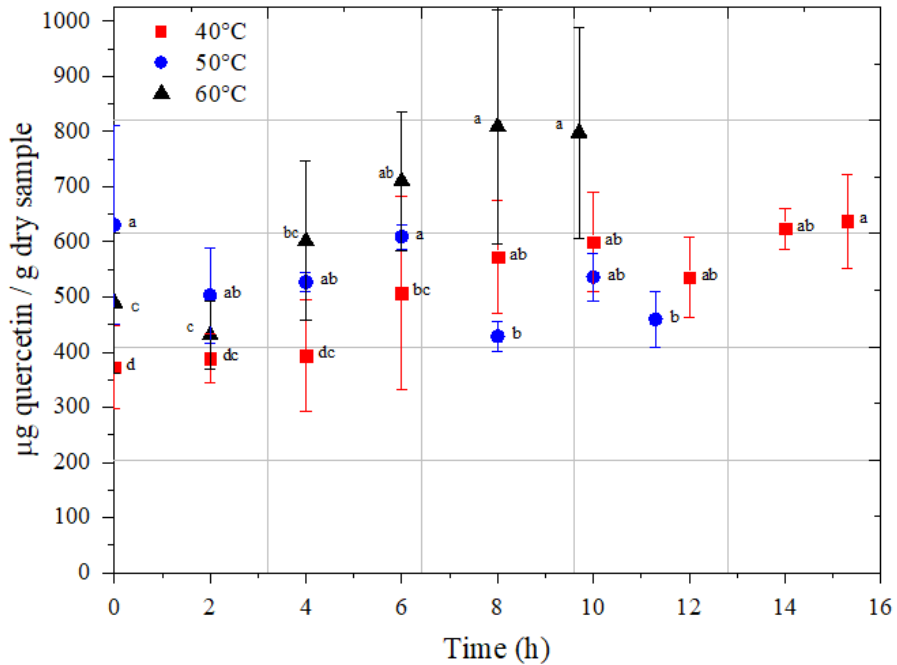

(a)

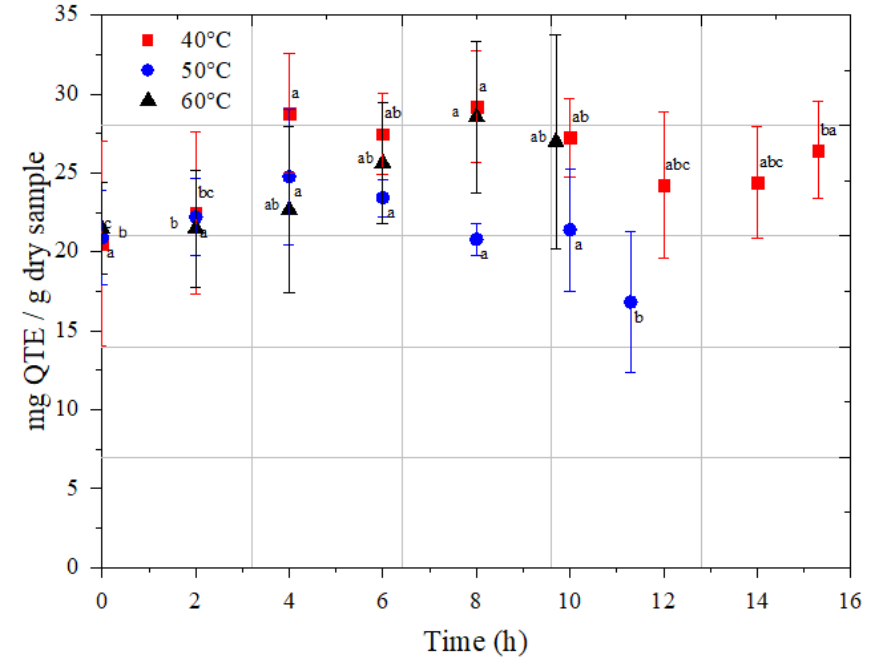

(b)

Figure 3. Active compounds concentration during drying time at different drying $\left(40,50,60{ }^{\circ} \mathrm{C}\right)$ : (a) Flavones and Flavonols; (b) Total proanthocyanidins. Different letters indicate significant differences ( $p<0.05)$, according to Duncan's test, at different times during drying.

In the quantification of vitamin $C$ (Figure 4), it was not possible to quantify this compound at $60{ }^{\circ} \mathrm{C}$, probably due to its thermosensitivity. Vitamin $\mathrm{C}$ is sensitive to high temperatures and long drying times, mainly due to its high exposure to oxygen [31]. Duzzioni and coauthors [10] evaluated the process of drying acerola by-product in a fixed-bed dryer, analyzing the effect of air velocity $(0.5$, $1.0 \mathrm{e} 1.5 \mathrm{~m} / \mathrm{s})$ and temperature $\left(40,50 \mathrm{e} 60^{\circ} \mathrm{C}\right)$ variables and reported that the ascorbic acid content was higher under the drying condition at $1.0 \mathrm{~m} / \mathrm{s}$ and $60{ }^{\circ} \mathrm{C}(126 \mathrm{mg} / 100 \mathrm{~g})$, indicating that the variations had a significant effect on vitamin $\mathrm{C}$ content.

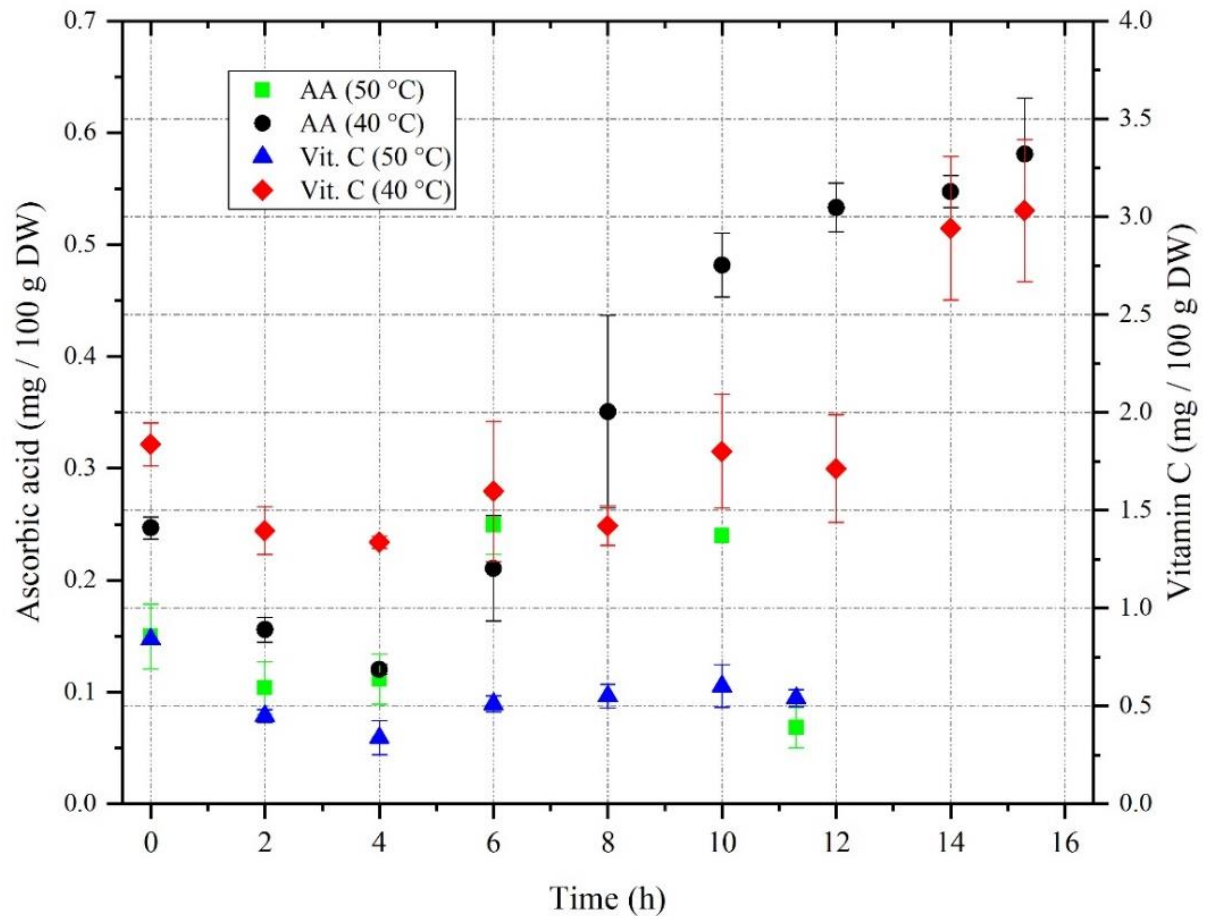

Figure 4. Concentration of Ascorbic Acid $(A A)$ and total vitamin $C$ ( $A A$ and dehydroascorbic acid /g dry weight) of acerola by-product during drying at 50 and $40{ }^{\circ} \mathrm{C}$. Where: Ascorbic acid (40 and $50^{\circ} \mathrm{C}$ ) on the left side and Vitamin $\mathrm{C}(40$ and $50^{\circ} \mathrm{C}$ ) on the right side.

At $50{ }^{\circ} \mathrm{C}$, the sample initially had $0.84 \mathrm{mg}$ of vitamin $\mathrm{C} \mathrm{mg} / \mathrm{g}$ of sample, of which $0.69 \mathrm{mg} / \mathrm{g}$ of sample was dehydroascorbic acid. At $40{ }^{\circ} \mathrm{C}$, initially the by-product presented $1.84 \mathrm{mg}$ of vitamin $\mathrm{C}$ $\mathrm{g}$ of sample, of which $1.59 \mathrm{mg} / \mathrm{g}$ was dehydroascorbic acid, indicating that $80 \%$ of the vitamin $\mathrm{C}$ was already oxidized due to fruit manipulation and transportation. At $50{ }^{\circ} \mathrm{C}$ the ascorbic acid content 
dropped by $54 \%$ of the total and the total content of vitamin C (ascorbic acid and dehydroascorbic acid) dropped by $35 \%$, which shows that much of the degradation ascorbic acid at that temperature was in the form of dehydroascorbic acid. At $40{ }^{\circ} \mathrm{C}$, at the end of drying, an increase in ascorbic acid and total vitamin $C$ levels was observed, this increase may be related to the efficiency of extraction of this compound from the sample at this stage of drying and to the high heterogeneity of the industrial by-product used (different percentages of peel, seed and residual pulp). Dehydroascorbic acid exhibits a biological activity equivalent to L-ascorbic acid [32], therefore there is no inconvenience of the presence of this compound in foods since they are also used by human metabolism.

\section{Total phenolic contents and ORAC assay}

The total phenolic contents is shown in Figure 5a. At the end of drying for each temperature values of $24.11 \pm 4.41,18.50 \pm 3.77$ and $28.57 \pm 4.04 \mathrm{mg} \mathrm{GAE} / \mathrm{g}$ dry sample were observed for 40 , 50 and $60{ }^{\circ} \mathrm{C}$, respectively. These values represented loss of $11.9 \%$ at $60{ }^{\circ} \mathrm{C}$, reduction of $31.5 \%$ for $50{ }^{\circ} \mathrm{C}$ and a significant increase of $26.3 \%$ for $40{ }^{\circ} \mathrm{C}$ from the initial values. Horuz and coauthors [31] reported that high temperatures and high drying times can lead to loss of phenolic compounds, as observed in this work, where higher temperature degradation occurred at $60^{\circ} \mathrm{C}$. López and coauthors [33] observed that long drying time associated with low temperatures $\left(50,60\right.$ and $\left.70{ }^{\circ} \mathrm{C}\right)$ would probably contribute to decreasing the protective effect against oxidative damage in blueberries.

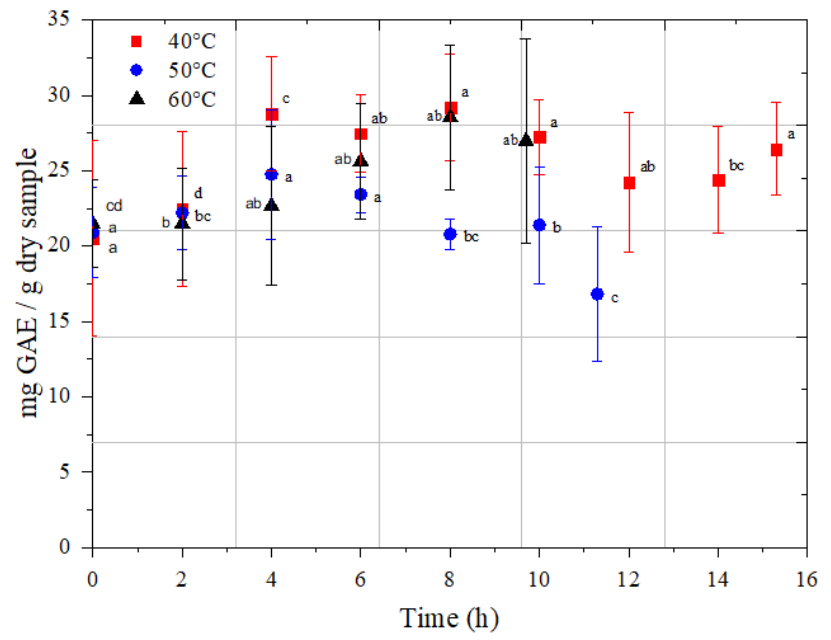

(a)

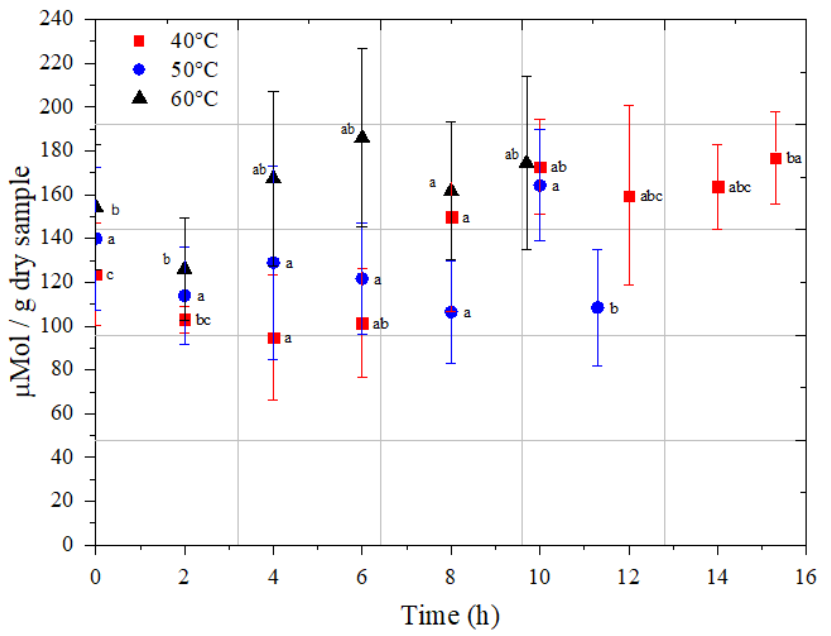

(b)

Figure 5. Antioxidant capacity as a function of drying time at different drying temperatures: (a) total phenolic contents; (b) Oxygen radical absorbance. Different letters indicate significant differences $(p<0.05)$, according to Duncan's test, at different times during drying.

Oxygen radical absorbance capacity assay results are presented in Figure $5 \mathrm{~b}$. In general, compared to initial values, an increase of $43 \%$ and $13 \%$ in ORAC results was observed, for drying at $40{ }^{\circ} \mathrm{C}$ (123.73 $\mu$ moles TE/100 g dry matter) and $60{ }^{\circ} \mathrm{C}(154.16 \mu$ moles TE/100 g dry matter), respectively. According to Capecka and coauthors [34], ambiguous connections may exist between the content of certain antioxidants and antioxidant activity, being difficult to explain only on the basis of quantitative analysis. In addition to the antioxidant level, other factors such as synergy and the constituents of the fruit can influence the antioxidant capacity [34].

Rodriguez and coauthors [35] evaluated antioxidant capacity of myrtle berries and found that drying at $80{ }^{\circ} \mathrm{C}$ showed higher concentration of antioxidant capacity, phenolic compounds and flavonoids. In addition, the lowest values of antioxidant compounds were observed for drying at 40 ${ }^{\circ} \mathrm{C}$, attributing this fact to the longer drying time. For the acerola by-product, despite the heterogeneity of the material, it was possible to observe that drying did not cause great loss of the antioxidant capacity in the by-product. Therefore, in addition to facilitating transportation and increasing durability, drying also maintains antioxidant properties.

\section{Scanning electron microscopy}

Analyzing the micrographs (Figure 6) of the acerola by-product, no ruptures were observed in the cell wall of the dry material (Figures $6 \mathrm{a}, \mathrm{b}, \mathrm{c})$. Probably, the temperature range used $\left(40-60^{\circ} \mathrm{C}\right)$ 
was not sufficient to cause changes in the material that could facilitate the process of extraction of the dried residue with respect to the fresh one. As the waste used comes from industrial processing, the different sizes observed are related to the material's heterogeneity.

Drosou and coauthors [36] studying grape pomace dehydration in an experimental air dryer reported that aqueous extracts produced from the dry residue showed higher yield relative to the extracts produced using the wet residue. Probably, the rupture and destruction of the cells caused by the drying, results in the formation of large cavities and intercellular spaces that facilitate the extraction of cellular substances [37].

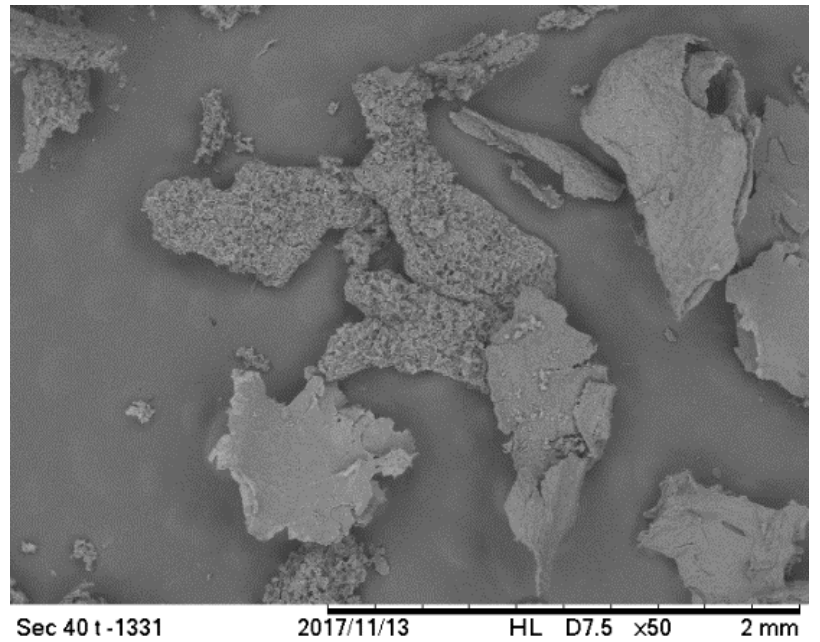

(a)

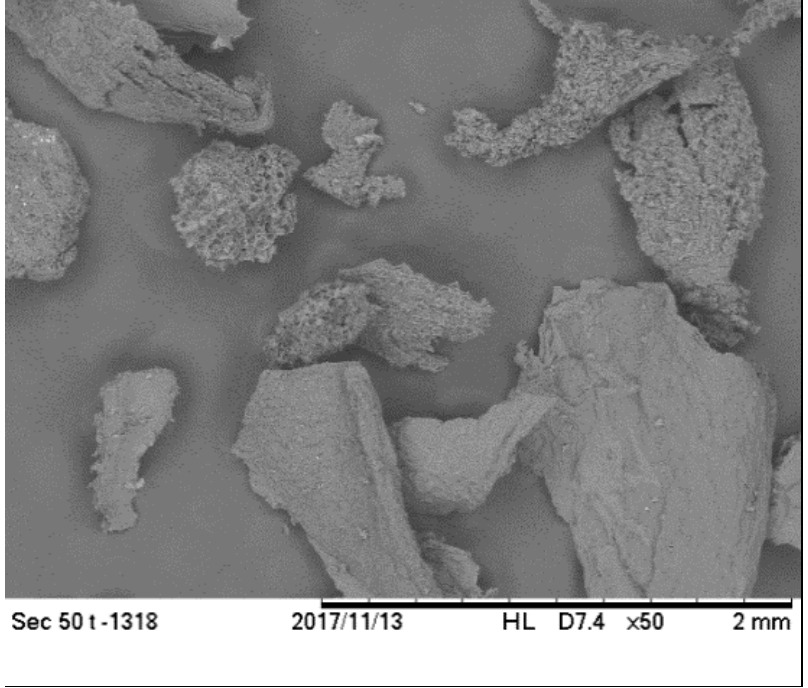

(b)

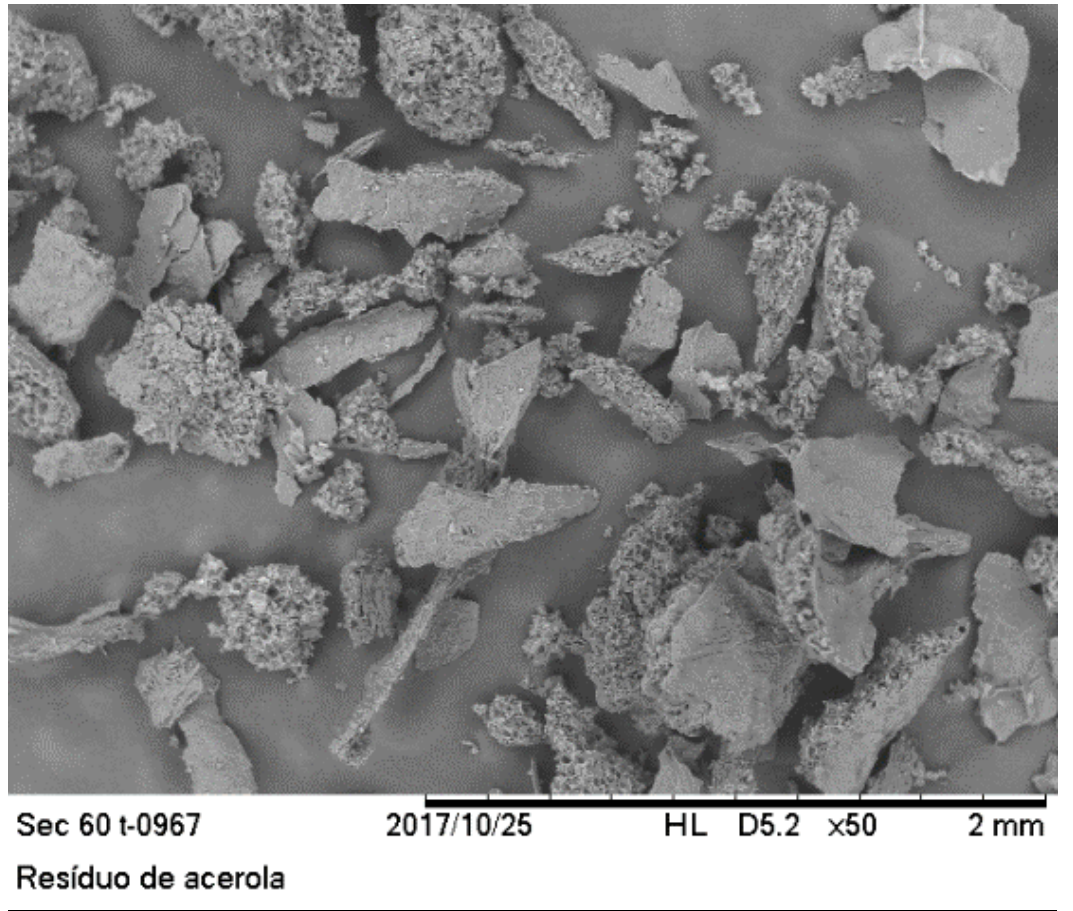

(c)

Figure 6. Scanning electron micrograph of acerola by-product at (a) $40^{\circ} \mathrm{C}$, (b) $50^{\circ} \mathrm{C}$ and (c) $60^{\circ} \mathrm{C}$.

\section{CONCLUSION}

Page model can predict the moisture content of acerola by-product at any point in the convection drying process at temperatures of 40,50 and $60^{\circ} \mathrm{C}$ and the behavior of the bioactive compounds during forced air convection drying in hot air was dependent on the drying temperature. From the proposed models, it was not possible to make a prediction based on vitamin $\mathrm{C}$, possibly due to the complexity of the residue used. However, the results of this study can collaborate to the development of new products developed from dry by-product, valuing industrial waste. 
Acknowledgements: This study was financed in part by the Coordenação de Aperfeiçoamento de Pessoal de Nível Superior - Brasil (CAPES) - Finance Code 001. The authors would like to thank to thank the São Paulo Research Foundation (FAPESP, Process number: 2016/16250-4) for financial support. R.A.C would like to thank the National Council for Scientific and Technological Development (CNPq, Process number: 304440/2016-7) for the productivity grant.

\section{REFERENCES}

1. USDA [United States Department of Agriculture]. Food Composition Databases. 2019 [cited 2021 April 23]. Available from: https://fdc.nal.usda.gov

2. Rufino SM, Alves RE, Brito ES, Pérez-Jiménez J, Saura-Calixto F, Mancini-Filho J. Bioactive compounds and antioxidant capacities of 18 non-traditional tropical fruits from Brazil. Food Chem. 2010;121(4):996-1002.

3. Matta VM, Moretti RH, Cabral LMC. Microfiltration and reverse osmosis for clarification and concentration of acerola juice. J. Food Eng. 2004;61(3):477-82.

4. Silva LMR, Figueiredo EAT, Ricardo NMPS, Vieira IGP, Figueiredo RW, Brasil IM, et al. Quantification of bioactive compounds in pulps and by-products of tropical fruits from Brazil. Food Chem. 2014;143:398-404.

5. Oliveira AC, Valentim IB, Silva CA, Bechara, EJ H, Barros MP, Mano CM, et al. Total phenolic content and free radical scavenging activities of methanolic extract powders of tropical fruit residues. Food Chem. 2009; 115(2):469-75.

6. Sousa MSB, Vieira LM, Silva MJM, Lima A. Caracterização nutricional e compostos antioxidantes em resíduos de polpas de frutas tropicais. Cienc. e Agrotecnologia. 2011;35:554-9.

7. Nobrega EM, Oliveira EL, Genovese MI, Correia RTP. The impact of hot air drying on the physical-chemical characteristics, bioactive compounds and antioxidant activity of acerola (Malphigia emarginata) residue. J. Food Process. Preserv. 2014;39(2):131-41.

8. Sancho SDO, Silva ARA, Dantas ANDS, Magalhaes TA, Lopes GS, Rodrigues S, et al. Characterization of the industrial residues of seven fruits and prospection of their potential application as food supplements. J. Chem. 2015; 264284:1-8.

9. Silva PB, Duarte CR, Barrozo MAS. Dehydration of acerola (Malpighia emarginata D.C.) residue in a new designed rotary dryer: Effect of process variables on main bioactive compounds. Food Bioprod. Process. 2016; 98:62-70.

10. Duzzioni AG, Lenton VM, Silva DIS, Barrozo MAS. Effect of drying kinetics on main bioactive compounds and antioxidant activity of acerola (Malpighia emarginata D.C.) residue. Int. J. Food Sci. Technol. 2013;48(5):1041-7.

11. Goula AM, Thymiatis K, Kaderides K. Food and Bioproducts Processing Valorization of grape pomace : Drying behavior and ultrasound extraction of phenolics. Food Bioprod. Process. 2016;100:132-44.

12. AOAC. Method 925.10: Solid (total) and moisture in flour, in: J. Dr. George W. Latimer (Ed.), Off. Methods Anal. AOAC Int., 16th ed., AOAC International., Gaithersburg, USA, 1998:32.1.03.

13. Tunde-Akintunde TY, Ogunlakin GO. Mathematical modeling of drying of pretreated and untreated pumpkin. J. Food Sci. Technol. 2013;50(4):705-13.

14. Ertekin C, Yaldiz O. Drying of eggplant and selection of a suitable thin layer drying model. J. Food Eng. 2004;63(3):349-59.

15. Lewis WK. The Rate of Drying of Solid Materials. J. Ind. Eng. Chem. 1921;13(5):427-32.

16. Henderson SM, Pabis S. Grain drying theory. I. Temperature effect on drying coefficient. J. Agric. Eng. Res. 1961;6:169-74.

17. Page GE. Factors influencing the maximum rates of air drying shelled corn in thin layers. [s.I.] Purdue University, 1949.

18. Overhults DG, White HE, Hamilton HE, Ross IJ. Drying soybean with heated air. Trans. ASAE. 1973; 16:112113.

19. Yağcıoğlu A, Değirmencioğlu A, Çağatay F.Drying characteristics of laurel leaves under different drying conditions. Proceedings of the 7th International Congress on Agricultural Mechanization and Energy. 1999;26-7.

20. Correia RTP, Borges KC, Medeiros MF, Genovese MI. Bioactive compounds and phenolic-linked functionality of powdered tropical fruit residues. Food Sci. Technol. Int. 2012; 18(6):539-47.

21. Neves LC, Silva VX, Pontis JA, Flach A, Roberto SR. Bioactive compounds and antioxidant activity in pre-harvest camu-camu [Myrciaria dubia (H.B.K.) Mc Vaugh] fruits. Sci. Hortic. 2015; 186:223-9.

22. Porter LJ, Hrstich LN, Chan BG. The conversion of procyanidins and prodelphinidins to cyanidin and delphinidin. Phytochemistry. 1986;25(1):223-30. 
23. Sánchez-Mata MC, Cámara-Hurtado M, Díez-Marqués C, Torija-Isasa ME. Comparison of high-performance liquid chromatography and spectrofluorimetry for vitamin $\mathrm{C}$ analysis of green beans (Phaseolus vulgaris L.). Eur. Food Res. Technol. 2000;210(3):220-5.

24. Singleton VL, Orthofer R, Lamuela-Raventós RM. Analysis of total phenols and other oxidation substrates and antioxidants by means of folin-ciocalteu reagent. Methods Enzymol. 1998;299:152-78.

25. Ou B, Hampsch-woodill M, Prior RL. Development and validation of an improved oxygen radical absorbance capacity assay using fluorescein as the fluorescent probe development and validation of an improved oxygen radical absorbance capacity assay using fluorescein as the fluorescent. J Agric Food Chem. 2001;49(10):461926.

26. Rodrigues E, Mariutti LRB, Faria AF, Mercadante AZ. Microcapsules containing antioxidant molecules as scavengers of reactive oxygen and nitrogen species. Food Chem. 2012;134(2):704-11.

27. Zhu A; Shen X. The model and mass transfer characteristics of convection drying of peach slices. Int. J. Heat Mass Transf. 2014; 72:345-51.

28. Araya-Farias M, Makhlouf J, Ratti C. Drying of Seabuckthorn (Hippophae rhamnoides L.) Berry: Impact of Dehydration Methods on Kinetics and Quality. Dry. Technol. An Int. J. 2011;29(3):351-9.

29. Sinha NK, Sidhu JS, Barta J, Wu JSB, Cano MP. Handbook of fruits and fruit processing handbook of fruits and fruit processing. Second Edition Edited by Library of Congress Cataloging-in-Publication Data, 2012.

30. Chamorro S, Gon I, Hervert-herna D. Changes in polyphenolic content and antioxidant activity after thermal treatments of grape seed extract and grape pomace. Eur. Food Res. Technol. 2012;234(1):147-55.

31. Horuz M, Bozkurt E, Karatas H, Maskan H. Effects of hybrid (microwave-convectional) and convectional drying on drying kinetics, total pheolics, antioxidant capacity, vitamin C, color and rehydration capacity of sour cherries. Food Chem. 2017;230:295-305.

32. Spinola V, Llorent-Martínez EJ, Castilho PC. Determination of vitamin C in foods: Current state of method validation. J. Chromatogr. A. 2014;1369:2-17.

33. López J, Uribe E, Vega-gálvez A, Miranda M, Vergara J, Gonzalez E, et al. Effect of air temperature on drying kinetics, vitamin c, antioxidant activity, total phenolic content, non-enzymatic browning and firmness of blueberries variety Óneil. Food Bioproc Tech. 2010;3(5):772-7.

34. Capecka E, Mareczek A, Leja M. Antioxidant activity of fresh and dry herbs of some Lamiaceae species. Food Chem. 2005;93(2):223-6.

35. Rodrıguez K, Ah-Hen K, Vega-Galvez A, Lopez J, Quispe-Fuentes I, Lemus-Mondaca R, et al. Changes in bioactive compounds and antioxidant activity during convective drying of murta (Ugni molinae T.) berries. J. Food Sci. Technol. 2014; 49(4):990-1000.

36. Drosou C, Kyriakopoulou K, Bimpilas A, Tsimogiannis D, Krokida, M. A comparative study on different extraction techniques to recover red grape pomace polyphenols from vinification byproducts. Ind. Crops Prod. 2015;75:1419.

37. Aguilera M, Stanley DW. Microstructural Principles of Food Processing and Engineering. 2nd ed. Gaithersburg, MD: Aspen Publishers, 1999.

2021 by the authors. Submitted for possible open access publication under the terms and conditions of the Creative Commons Attribution (CC BY NC) license (https://creativecommons.org/licenses/by-nc/4.0/). 